\title{
8
}
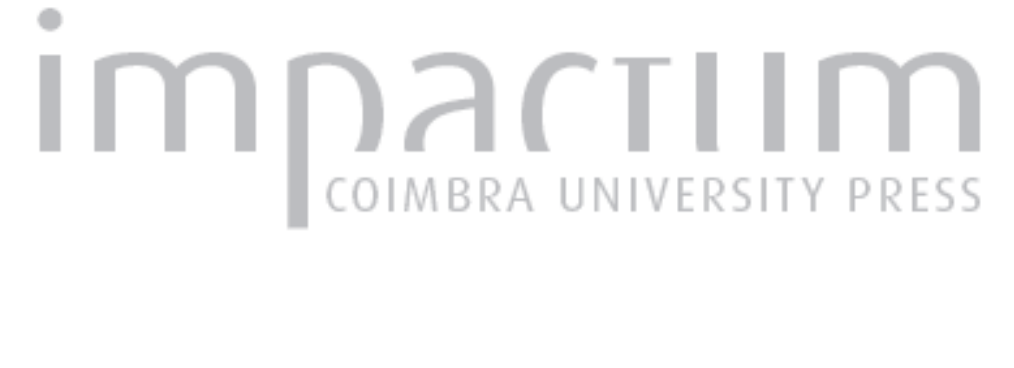

\section{A evolução da malha urbana de uma vila ribeirinha: contributos para o conhecimento do caso de Coruche}

Autor(es): $\quad$ Correia, Ana Maria Diamantino

Publicado por: Faculdade de Letras da Universidade de Coimbra, Instituto de História

URL

persistente:

URl:http://hdl.handle.net/10316.2/28056

DOI: $\quad$ DOI:http://dx.doi.org/10.14195/0870-4147_43_10

Accessed : $\quad$ 26-Apr-2023 10:36:38

A navegação consulta e descarregamento dos títulos inseridos nas Bibliotecas Digitais UC Digitalis, UC Pombalina e UC Impactum, pressupõem a aceitação plena e sem reservas dos Termos e Condições de Uso destas Bibliotecas Digitais, disponíveis em https://digitalis.uc.pt/pt-pt/termos.

Conforme exposto nos referidos Termos e Condições de Uso, o descarregamento de títulos de acesso restrito requer uma licença válida de autorização devendo o utilizador aceder ao(s) documento(s) a partir de um endereço de IP da instituição detentora da supramencionada licença.

Ao utilizador é apenas permitido o descarregamento para uso pessoal, pelo que o emprego do(s) título(s) descarregado(s) para outro fim, designadamente comercial, carece de autorização do respetivo autor ou editor da obra.

Na medida em que todas as obras da UC Digitalis se encontram protegidas pelo Código do Direito de Autor e Direitos Conexos e demais legislação aplicável, toda a cópia, parcial ou total, deste documento, nos casos em que é legalmente admitida, deverá conter ou fazer-se acompanhar por este aviso. 



\title{
A evolução da malha urbana de uma vila ribeirinha: contributos para o conhecimento do caso de Coruche*
}

\author{
Ana Maria Diamantino Correia \\ Mestranda em História Contemporânea, Faculdade de Letras da Universidade de Coimbra \\ Museu Municipal de Coruche \\ anamariadcorreia@gmail.com
}

Resumo:

Com uma relação muito forte com o rio, a vila de Coruche foi, ao longo dos séculos, crescendo numa faixa contínua entre o curso de água e o acidentado do terreno. Partindo da premissa de que são vários os agentes que, em conjunto, participam, directa e indirectamente, no evoluir de um qualquer aglomerado urbano, avaliámos elementos de teor geográfico, mas também económico, político e social, não excluindo os factores naturais, imprevisíveis às vontades humanas.

São analisados aspectos vários do urbanismo histórico da vila, introduzindo novos conhecimentos consubstanciados em fontes inéditas, que contribuem de forma significativa para uma melhor apreensão e compreensão da memória e identidade local.

Palavras chave:

Malha urbana; Sorraia, rio; Coruche.
Abstract:

With a very strong relationship with the river, the town of Coruche has grown, over the centuries, in a continuous strip between the water course and the uneven ground. Starting from the premise that there are several agents that are involved together, directly and indirectly, in the evolution of any urban settlement, we evaluated elements of geographic content, but also economic, political and social, not excluding natural factors, unpredictable to human wills.

Several aspects of the urbanistic history of the town are analized, introducing new knowledge collected from unpublished sources which contributes significantly to a better apprehension and understanding of local identity and memory.

Keywords:

Urban network; Sorraia, river; Coruche.

\footnotetext{
* Agradeço à Professora Doutora Maria Antónia Lopes a leitura crítica deste texto.
} 
O surgir de um determinado aglomerado populacional no espaço e o seu posterior desenvolvimento e manutenção é sempre o resultado de diversos condicionantes e factores. As condições naturais, os agentes humanos, a(s) vontade(s) e poderes político, religioso e económico, trabalham em conjunto deixando a sua marca no património construído. É ele o espelho de uma realidade local, resultado de uma conjuntura particular e mais abrangente, mas é acima de tudo um elemento de identidade e memória de uma população.

Este conjunto de elementos poderá ter ocorrido na construção e desenvolvimento do tecido urbano da vila de Coruche. Situada na bacia hidrográfica do rio Tejo, numa zona de fronteira entre a paisagem ribatejana e alentejana. Implantada entre o monte, a Norte, e o rio Sorraia, a Sul, a vila desenvolve-se numa faixa ao longo do leito do rio, apresentando-se estes como factores modeladores e condicionantes do desenvolvimento do próprio núcleo urbano. Importa desde já ressaltar a importância, podemos dizê-lo, desde tempos muito recuados, que o rio e as águas deste tiveram para aqueles que nas suas margens habitaram. Todavia, seria redutor afirmar que só os elementos naturais influenciam a configuração urbana. A dimensão humana nunca poderia ser apartada desta questão.

O presente artigo debruça-se sobre a análise destes múltiplos factores. Se por um lado é feita uma sistematização dos conhecimentos existentes até ao momento, por outro acrescentam-se novas informações, recolhidas a partir da análise de fontes inéditas. É pois uma primeira abordagem ao urbanismo histórico da vila de Coruche e também por isso o texto abarca um largo espectro temporal.

\section{Breve enquadramento histórico}

Se são ainda escassas as informações acerca dos habitantes que residiriam no espaço ocupado por Coruche no momento da chegada das tropas romanas, em meados do século II a.C. ${ }^{1}$, por outro lado, os inúmeros vestígios romanos encontrados apontam para uma ocupação rural ao longo de todo o vale do Sorraia, associada a uma utilização intensa do rio como via de comunicação por excelência ${ }^{2}$. De salientar que o Sorraia, como afluente do rio Tejo, era fundamental no escoamento e importação de produtos diversos, oriundos de vários pontos do império romano.

1 Vasco Gil Mantas, "Os Romanos na região de Coruche", in Cristina Calais (coord.) O Homem e o Trabalho - a magia da mão, Coruche, Câmara Municipal de Coruche/Museu Municipal, 2003,p. 53.

2 Idem, p. 55-56. 
No que diz respeito ao período subsequente, o território de Coruche não foi imune ao domínio visigótico, embora pouco documentado, nem tão pouco à presença islâmica ${ }^{3}$. O controlo deste espaço - habitado por um grande número de cristãos (moçárabes) - trespassado por várias vias e viajantes terá obrigado à construção de uma pequena estrutura militar, possivelmente em taipa, ainda ao tempo do domínio mouro 4 . A elevação, onde hoje se encontra a ermida de Nossa Senhora do Castelo, assume-se como um elemento que, ao longo dos tempos, teve a maior relevância na vida dos que habitaram por estas paragens, como por exemplo, ao oferecer a desejada protecção em momentos de grande instabilidade 5 .

Coruche, com o castelo, que, segundo Margarida Ribeiro, já estaria completamente destruído em $1532^{6}$, assume-se, sob o ponto de vista militar, como um lugar estratégico de monta no período da Reconquista, tendo sido tomado aos mouros, em 1166, por D. Afonso Henriques ${ }^{7}$. Esta importância deve-se à posição de domínio sobre a várzea, sobranceira ao Além-Tejo ainda mouro, elemento-chave do sistema defensivo no eixo Évora/Santarém, com ligação fluvial a Lisboa ${ }^{8}$, razão que explica a doação do castelo de Coruche, em 1176, por aquele monarca à ordem militar dos freires de Évora, mais tarde chamada de Avis. A esta doação estariam implícitos motivos de ordem defensiva de um território fronteiriço, cuja manutenção se apresentava fulcral.

3 Fernando Branco Correia, "Coruche medieval: Do final do Império Romano ao crepúsculo da Idade Média”, in Cristina Calais (coord.) O Homem e o Trabalho-a magia da mão, Coruche, Câmara Municipal de Coruche/Museu Municipal, 2003, p. 71.

4 Idem, ibidem, p. 72.

5 Porém, de acordo com um estudo do território, esta elevação não seria a que possibilita um melhor domínio visual sobre a paisagem, se comparada com outros, como por exemplo, o Monte do Lacrau, a Oeste, e o Cabeço do Pé da Erra, a Este, perto da vila da Erra. Segundo o autor, a escolha deste local pode ser explicada pela provável proximidade em relação aos corredores naturais de passagem. Cf. Vasco Manuel Mantas, Carta de Potencial de Identificação de Sítios de Interesse Arqueológico de Coruche, Câmara Municipal de Coruche/Museu Municipal, Texto policopiado, 2008, p. 94

6 Margarida Ribeiro, Estudo Histórico de Coruche, Coruche, Câmara Municipal de Coruche/ /Museu Municipal, 2009 [1. a edição 1959], p. 83. Todavia, nas Memórias Paroquiais, que a autora transcreve, é referida a existência, à data, de alguns vestígios do castelo de Coruche (Doc. n. ${ }^{\circ}$ 42, p. 299).

7 Sobre este assunto veja-se José Mattoso, "Coruche na Idade Média”, Boletim Cultural, Assembleia Distrital de Santarém, Santarém, 1989, p. 17; Hermenegildo Fernandes, "Quando o Além-Tejo era "fronteira": Coruche da militarização à territorialização", in As Ordens Militares e as Ordens de Cavalaria na Construção do Mundo Ocidental, Edições Colibri/Câmara Municipal de Palmela, 2002, p. 472.

8 Fernando Branco Correia, «art. cit.», p. 74. 
Nos anos de 1180 e 1181, as forças almóadas tentam reconquistar a cidade de Évora, pelo que na impossibilidade de o conseguirem, e na hipótese de rumarem a Santarém, dirigem-se a Coruche, onde provocam a destruição, senão total, pelo menos parcial, da estrutura militar aí existente, associada a inúmeras mortes, havendo notícia de que a vila terá ficado desabitada9 .

Um ano mais tarde, em 1182, com o território sob o domínio cristão, mostra-se por demais pertinente a fixação de população, também como forma de manutenção do poder sobre o espaço. Assim se explica a atribuição da carta de foral nesse ano, por parte de D. Afonso Henriques, a Coruche ${ }^{10}$.

\section{A malha urbana medieval/moderna}

Os momentos de estabilidade que se seguiram à Reconquista fixam a população definitivamente no sopé do monte, junto ao rio, onde se desenvolverá o aglomerado urbano que hoje conhecemos.

Se a última investida almóada, que atingiu o castelo de Coruche, ocorreu em $1184^{11}$, poderá denunciar a inexistência de uma comunidade estável neste local; em 1201, surge o testemunho da compra de uma propriedade no termo de Coruche, o que, segundo Hermenegildo Fernandes, constitui o primeiro testemunho de uma sociedade em actividade ${ }^{12}$.

\subsection{As igrejas da vila medieval}

No período medieval, a vila apresenta mais do que uma igreja, como o atesta, em 1214, a composição entre o bispo de Évora, Soeiro II, e o mestre da Ordem de Avis, D. Fernando Eanes, ao referir-se no seu texto às "igrejas de Coruche"13. Uma seria a igreja de S. Pedro, localizada no extremo nascente do aglomerado, a igreja de S. João Baptista, na praça central, e a igreja de S. Miguel, na entrada poente da vila.

A igreja de S. Pedro, ainda que se desconheça a sua data de construção, sabe-se, no entanto, que já existia em 1222, como o comprova a venda efectuada, em Abril desse ano, por Pedro Anes, prior da igreja de S. Pedro, a D. Honório

9 Idem, ibidem, p. 74.

${ }^{10}$ Sobre o foral medieval de Coruche deve consultar-se o estudo de Filipa Roldão e Joana Serafim, O Foral de Coruche de 1182 - Estudo, Edição e Tradução, Câmara Municipal de Coruche/Museu Municipal (no prelo).

${ }^{11}$ Hermenegildo Fernandes, «art. cit.», p. 459.

${ }^{12}$ Idem, ibidem, p. 462.

${ }^{13}$ Idem, ibidem, p. 472. 
Mendes, comendador de Coruche, de parte de uns moinhos existentes no Carvalhal, pela quantia de 60 morabitinos $^{14}$. Sete anos mais tarde (1229) o mesmo comendador compra uma casa, por 10 maravedis, situada na freguesia de S. Pedro de Coruche ${ }^{15}$.

Esta é uma igreja de uma só nave que embora tenha sofrido, ao longo do tempo, várias transformações, dentro e fora de portas, apresenta o seu interior um revestimento de azulejos do século XVII, vestígios de sucessivos usos, não obstante a sua traça primitiva ser tipicamente medieval.

$\mathrm{O}$ mesmo aconteceria com as duas outras igrejas existentes no mesmo período na vila, das quais se desconhece igualmente as respectivas datas de edificação. A antiga igreja de S. Miguel, desde o século XVII sob a invocação de Santo António, situar-se-ia sensivelmente no sítio onde hoje encontramos a igreja de invocação a este santo $^{16}$, localizada naquela que seria, à data, a entrada oeste da vila, no início da Rua Direita. À semelhança da igreja de S. Pedro também a igreja de Santo António se encontra documentada desde $1222^{17}$.

A matriz da vila, de invocação a S. João Baptista situava-se no largo principal, hoje denominado de Praça da Liberdade. O testemunho mais antigo da sua existência data de $1221^{18}$ e a única descrição que se conhece é feita pelo pároco de Coruche, Luís António Leite Pitta, na resposta aos inquéritos de $1758{ }^{19}$.

${ }^{14}$ Idem, ibidem, p. 480.

${ }_{15}$ Margarida Ribeiro, Estudo..., cit., p. 112.

${ }^{16}$ Idem, p. 116. A monografia de Margarida Ribeiro continua a ser, indiscutivelmente, o ponto de partida para o conhecimento do concelho de Coruche. Porém, não pretendendo desmerecer o valor da obra, são várias as situações em que a autora não especifica as fontes que utilizou. A localização da igreja de S. Miguel de Coruche é um exemplo do que acabámos de dizer. Importa referir que Maria Ângela Beirante avança com a hipótese de a igreja de S. Miguel tivesse lugar no espaço do castelo (Cf. Maria Ângela Beirante, "Salvação e memória de três Donas Coruchenses do século XIV", in Estudos em homenagem ao Professor Doutor José Marques, vol. 3, Porto, Faculdade de Letras da Universidade do Porto, 2006, p. 246).

${ }^{17}$ Hermenegildo Fernandes, «art. cit.», p. 472.

${ }^{18}$ Margarida Ribeiro, Estudo..., cit., p. 115.

19 “[...] não tem Naves, hé de Tilhado de duas Agoas, forada de Pinho, tem Capella Mor de Abobeda de tijollo com rettabulo e Tribuna de Emtalhado, dois altares colatraes, o do Evangelho de Nossa Senhora da Conceissão, e o da Episttulla do Rozario [...] e no mesmo lado Capela do Santissimo Sacramento de Abobeda [...] tem mais no mesmo lado da Episttola huma capella da Senhora da Vitoria com rettabollo de Inttalhado [...] e do mesmo lado huma Capela das Almas com hum Painel de São Miguel Pinttado [...] Do lado do Evangelho tem a Capela de Santta Catherina com rettabollo de Inttalhado [...]." in Margarida Ribeiro, Estudo..., cit., Doc. n. ${ }^{\circ} 42$, p. 297. 
Tudo isto significa que nos inícios do século XIII, Coruche, que durante tanto tempo desempenhou a instável função de fronteira, dispunha já de uma ocupação cristã perfeitamente sólida e organizada. Tanto assim é que, em 1248, D. Afonso III doa o padroado das igrejas de S. Miguel, S. Pedro e S. João Baptista ao Mestre de Avis.

No devir, a matriz viria a ser, além do mais, a sede da Real Colegiada de São João Baptista (uma das mais antigas e ricas do reino), pólo aglutinador da vida religiosa de Coruche medieval, situada num ponto central do aglomerado urbano, que exercia com certeza um grande poder no seio da vila e seu termo. O edifício da igreja, no conjunto da praça, ganharia, ao longo dos séculos, uma volumetria considerável ${ }^{20}$, conforme se constata tanto na planta da vila de 1789 (Figura 1) como no levantamento parcial da praça realizado em 1824 (Figura 2) ${ }^{21}$.

\section{MAPPA TOPOGRAPHİCO \\ DA VILLA DE CORUCHE}

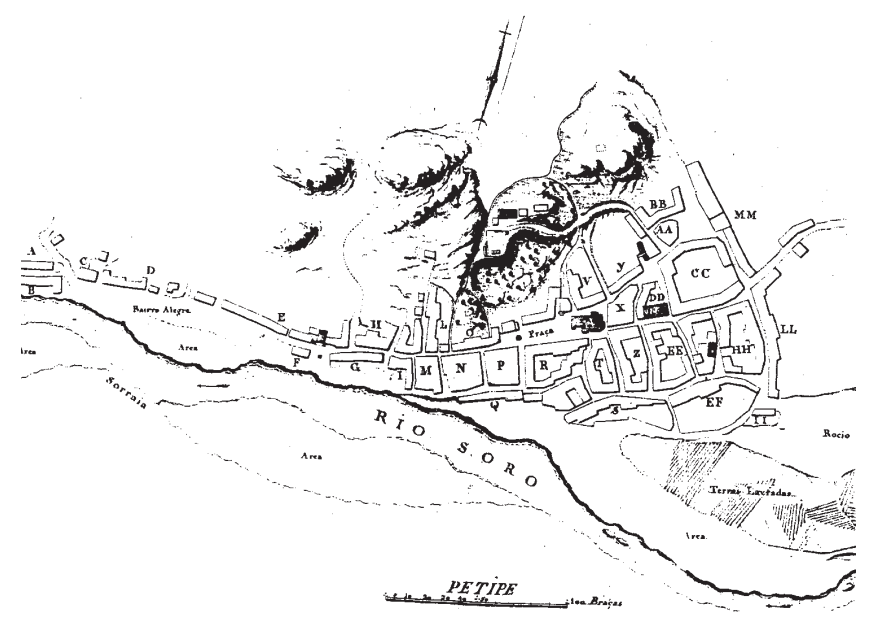

Figura 1 - Mapa da vila de Coruche, datado de 1789, publicado por

Manuel Nazareth e Fernando de Sousa em A demografia portuguesa em finais do Antigo Regime - aspectos sociodemográficos de Coruche, vol. 4, Livraria Sá da Costa Editora, Lisboa, 1983, p. 69.

${ }^{20}$ A imponência do edifício da igreja matriz, sobrepondo-se à volumetria das construções circundantes, era algo recorrente e com significado próprio no período em questão. Cf. Amélia Aguiar Andrade, Um espaço urbano medieval: Ponte de Lima, Lisboa, Livros Horizonte, 1990, p. 72 .

${ }^{21}$ Processo de edificação da igreja matriz de Coruche, Biblioteca Nacional (Lisboa), ACL-MCO/Cx5, Maço 5. Ambos os elementos iconográficos que aqui apresentamos, muito embora posteriores ao plano cronológico que norteia este texto, considerámos relevante a sua inclusão neste ponto. A eles retomaremos mais adiante. 


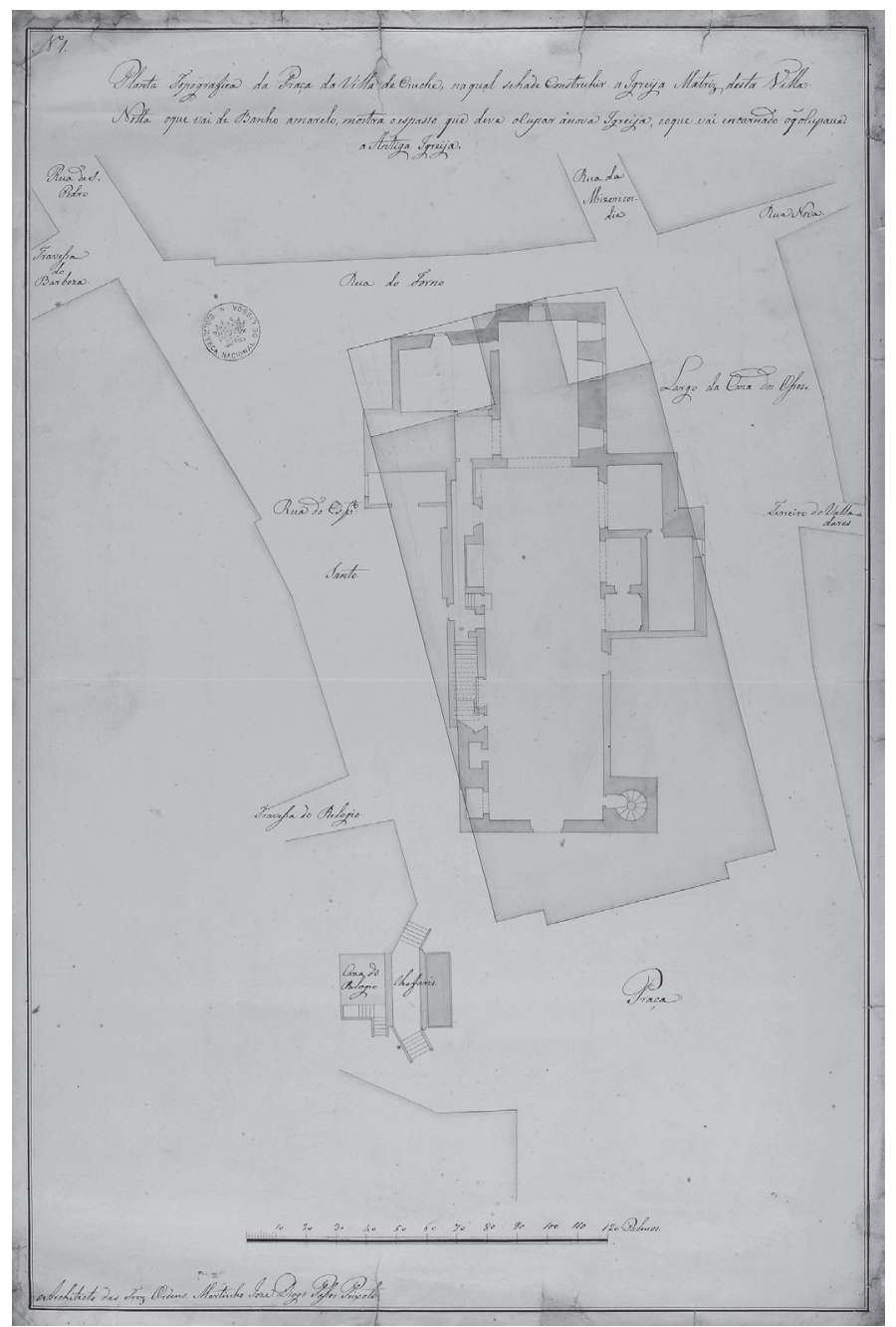

Figura 2 - Levantamento da igreja matriz existente na praça e o projecto de implantação da nova igreja que nunca foi executada. Biblioteca Nacional (Lisboa).

Ao contrário das igrejas de S. Pedro e de Santo António que, grosso modo, têm os seus altares orientados de Norte para Sul, pode igualmente verificar-se na planta do século XVIII, que a igreja matriz ${ }^{22}$ seguia aquele que era o sentido

${ }^{22}$ A implantação da igreja da Misericórdia, alvo de atenção mais à frente, e da igreja de Nossa Senhora do Castelo coincide com o que é dito sobre a igreja matriz. 
clássico dos templos cristãos medievais com orientação Este/Oeste, ou seja, o altar-mor estaria direccionado para Jerusalém, onde nasce a luz e está a origem da fé.

Na chamada lista das igrejas de 1320, publicada por Fortunato de Almeida, a igreja de S. João Baptista está taxada em 248 libras, enquanto que S. Miguel (Santo António) e S. Pedro receberiam 238 e 228 libras, respectivamente ${ }^{23}$. Estas rendas provinham em grande medida dos bens deixados às instituições, das capelas instituídas em cada uma das igrejas, que rendiam maioritariamente em géneros.

Nas igrejas da vila se implantaram capelas particulares, como acontecia frequentemente. Assim sucedeu, por exemplo com três mulheres, que, se não eram oriundas da vila, aqui foram moradoras, como ditam os seus testamentos. São elas, Maria Raimundo (15 de Outubro de 1339), Maria Simões (3 de Dezembro de 1348) e Maria Eanes Garavinha (19 de Maio de 1394), que deixaram tais fundações, no intuito de sufragar perpetuamente as suas almas $^{24}$. Se as duas primeiras instituem as ditas capelas na igreja de S. João, a terceira opta pela igreja de S. Miguel. Maria Raimundo, pertencente a uma família de alta condição social, com ligações à corte, pede inclusivamente no seu testamento para ser enterrada na igreja de S. João, em frente ao altar de Santa Clara, sob uma pedra que mandara vir da Flandres e onde já se encontrariam dois cavaleiros com quem fora casada ${ }^{25}$.

Data do reinado de $\mathrm{D}$. Afonso $\mathrm{V}$ a referência mais antiga que se conhece aos paços do concelho ${ }^{26}$. Normalmente fronteiro à sede do poder concelhio, encontrar-se-ia o pelourinho, marco indiscutível do poder e autonomia municipal. Além deste, a cadeia era outro dos elementos fundamentais nos concelhos. Em Coruche, embora tivesse havido tentativas por parte do comendador da Ordem de Avis para controlar este espaço, tal nunca se verificou, ao permanecer a cadeia sob a alçada do concelho ${ }^{27}$.

${ }^{23}$ Fortunato de Almeida, História da Igreja em Portugal, vol. IV, Porto-Lisboa, Livraria Civilização, 1971, p. 135.

${ }^{24}$ Maria Ângela Beirante, «art. cit.», p. 247.

${ }^{25}$ Idem, ibidem, p. 252.

${ }^{26}$ Margarida Ribeiro, Estudo..., cit., p. 154; Fernando Branco Correia, «art. cit.», p. 80.

${ }^{27}$ Idem, ibidem, p. 145-147. No capítulo intitulado "Demandas com o Comendador e o engrandecimento do poder municipal" (p. 141-148) pode constatar-se as constantes discórdias que sempre envolveram estas duas esferas de poder: o comendador da Ordem de Avis e os homens 
A existência de uma Rua Direita é, como se sabe, muito frequente na toponímia urbana medieval. Em Coruche, a Rua Direita era a rua principal no contexto urbano da vila, e ainda hoje conserva esta primazia como eixo estruturante no âmbito do centro histórico. Apresenta uma configuração paralela ao rio Sorraia, a meio termo entre a elevação sobranceira ao aglomerado urbano e o curso do rio, indo ao encontro da praça principal, onde se subdivide em duas artérias, as actuais Rua de S. Pedro e a Rua da Misericórdia.

Pode dizer-se que a existência deste curso de água, associado à presença de vias de comunicação com uma configuração paralela ao próprio rio, sendo a artéria principal atravessada por uma trama de ruas, becos e azinhagas de importância secundária, definem indiscutivelmente a malha urbana da vila de Coruche desde tempos antigos e permanecem perceptíveis a um olhar actual. A par destes elementos, a localização da igreja matriz, já referida, funcionava como factor responsável pela configuração da tessitura do aglomerado urbano.

Mas de que forma estaria organizado o povoamento no interior da vila neste período? A este respeito faltam estudos que respondam à questão. No texto do foral afonsino, o rei menciona a existência de cristãos, judeus e mouros, o que pressupõe a coexistência destes três grupos religiosos, embora vivendo certamente em espaços distintos. Como se sabe, regra geral, as judiarias estariam instaladas no interior do centro urbano, enquanto que as mourarias se situariam nos limites, não deixando de ser zonas bem demarcadas na malha urbana, para além de exclusivas ${ }^{28}$.

Segundo a informação conhecida, em Coruche, cristãos e judeus terão vivido conjuntamente até $\mathrm{D}$. Afonso $\mathrm{V}$ determinar que os últimos se juntassem e constituíssem uma judiaria, deixando, desta forma, de viver "em cristandade" 29 . Fernando Branco Correia acredita que tal não aconteceu de facto, dada a inexistência de qualquer referência à judiaria de Coruche ${ }^{30}$, enquanto Margarida Ribeiro, embora não tenha conseguido determinar a sua localização, alude a dois documentos que lhe fazem menção, acrescentando ainda que esta terá sido extinta, à semelhança das demais existentes no reino, em 1496, aquando da

do concelho. Desta forma, foram vários os monarcas chamados a interceder pelos interesses de ambas as partes.

${ }^{28}$ Sérgio Luís Carvalho, Cidades Medievais Portuguesas, Lisboa, Livros Horizonte, 1989, p. 42. A este respeito pode ainda consultar-se os trabalhos de Amélia Aguiar Andrade, Um espaço urbano medieval..., «art. cit.»; e Rita Costa Gomes, A Guarda Medieval: posição, morfologia e Sociedade (1200-1500), vol. 9-10, Lisboa, Livraria Sá da Costa Editora, 1987.

${ }^{29}$ Margarida Ribeiro, Estudo..., cit., Doc. n. ${ }^{\circ}$ 31, p. 274.

${ }^{30}$ Fernando Branco Correia, «art. cit.», p. 79. 
expulsão dos judeus por D. Manuel ${ }^{31}$. A tradição oral apelida a actual Travessa do Arco, pequena artéria da Rua Direita, próxima da Praça da Liberdade, como tendo sido em tempos o Beco da Judiaria, embora tal não possa ser confirmado por documentação que o sustente.

Quanto à existência de uma possível mouraria, não é conhecida, de momento, qualquer menção a este respeito no que trata a Coruche. Tal pode dever-se, por um lado, à inexistência de uma separação física ou, por outro lado, ao desaparecimento intencional de qualquer vestígio da sua localização.

Segundo o Capítulo Terceiro das Cortes de Évora, de 1473, Coruche contaria à data com uma população inferior a 400 vizinhos $^{32}$. Ora, no Numeramento mandado executar, em 1527, por D. João III, terminado em 1532, a vila e o seu termo contam com 341 moradores, sendo que só a vila detinha $211^{33}$.

No mesmo documento são fornecidas, entre outras, informações sobre as confrontações e distâncias (em léguas) entre as sedes administrativas do reino e os seus termos. Quanto a Coruche, a vila distava 6 léguas de Santarém, a Norte, e, a Nascente, entraria no termo da Vila Nova da Erra meia légua passada e andando outra meia légua entraria na dita vila. Caminhando para Sul, qualquer viandante teria que percorrer 7 léguas para chegar ao termo de Montemor-o-Novo e mais 3 para alcançar o aglomerado urbano. Para Poente, a vila de Coruche distava 4 léguas da sede administrativa de Benavente e as mesmas 4 léguas, na direcção de Noroeste, a separavam de Salvaterra ${ }^{34}$.

Coruche seria um lugar de passagem de inúmeros viajantes, estando inclusivamente na rota dos itinerários reais rumo a Évora ${ }^{35}$, uma vez que se encontrava na proximidade de eixos de comunicação, alguns deles herdeiros de vias do período romano ${ }^{36}$. Assim se explica a criação da estalagem em Coruche, a pedido do comendador da Ordem de Avis Diogo Lopes de Brito a D. João I, em 1403. Estes estabelecimentos, que não raras vezes funcionavam como hospitais, serviriam de ponto de abrigo aos que estavam de passagem, pelo que

${ }^{31}$ Margarida Ribeiro, Estudo..., cit., p. 123-124.

${ }^{32}$ Idem, ibidem, p. 106. A autora depreende este número, que atribui como o motivo para a supressão da jurisdição particular de juízes dos órfãos.

${ }_{33}$ Anselmo Braamcamp Freire, Archivo Historico Portuguez, vol. IV, Lisboa, 1906, p. 351.

${ }^{34}$ Idem, p. 351. Sobre este assunto consulte-se Suzanne Daveau, "A descrição territorial no Numeramento de 1527-32”, Penélope, n. ${ }^{\circ} 21$, Lisboa, 2001, p. 7-39.

${ }^{35}$ Para uma descrição sobre o papel de Coruche no mapa dos itinerários reais, veja-se Cristina Calais, "O Rio, o curso da História”, in Vagas Leves - Rostos do Rio, Museu Municipal de Coruche, 2003, p. 11-30.

36 Veja-se de Vasco Gil Mantas, «art. cit.», p. 53-69 e do mesmo autor "A Rede Viária de Scallabis", in De Scallabis a Santarém, Lisboa, Museu Nacional de Arqueologia, 2002, p. 107-112. 
a estes era oferecida uma refeição, muitas vezes ligeira, água e fogueira para se aquecerem, bem como alimento e espaço para resguardar as montadas ${ }^{37}$.

Depois da criação da dita estalagem, em Coruche, foi percebido que não era o único local que recebia viajantes. Por este motivo, D. Manuel, no foral que concedeu a Coruche, em 1513, atribui à Ordem de Avis o monopólio da estalagem, consentindo, contudo, que, no caso de sobrelotação da mesma, os viajantes pudessem ser recolhidos em casa das pessoas da vila. Em documentação de 1632 é referenciada uma "Rua das Estalagens" em Coruche ${ }^{38}$. Além disso, na toponímia antiga existiu a Rua da Estalagem (actual Rua Padre Evaristo do Rosário Guerreiro), situada em pleno centro, com sentido Sul/Norte, e ligação à actual Praça da Liberdade e à Rua Direita ${ }^{39}$.

Em Coruche medieval, como, de resto, na maioria dos aglomerados urbanos deste período, existiam várias confrarias e irmandades. Uma delas, a irmandade do Espírito Santo, cuja capela estava adossada à igreja matriz de S. João Baptista, perceptível na figura 2 , bem como na toponímia que a imagem apresenta. Era detentora de um hospício, enquanto a de Nossa Senhora da Purificação, igualmente apelidada das Candeias, possuía um hospital. A irmandade de S. Lázaro seria a proprietária da gafaria ${ }^{40}$.

À semelhança de instituições similares, a gafaria situar-se-ia fora dos limites da vila ${ }^{41}$. Num documento de 1434, relativo às demarcações dos termos do concelho de Coruche e Santarém, surge a indicação "Sam Lazaro que he junto com ho pinhall da villa de Curuche" e num outro documento de 1508 a referência "por detrás delle [castelo] per hu sohia de ser a gafaria” ${ }^{42}$. Assim se confirma tanto a existência de uma gafaria em Coruche como a sua possível localização à entrada do castelo, portanto fora do aglomerado populacional. De referir que o mesmo documento anuncia que à data em que este foi feito, a dita gafaria já não existia.

Claude de Bronseval, monge cisterciense, que acompanha D. Edme de Saulieu - abade de Claraval -, na viagem de visitação aos mosteiros da

${ }^{37}$ José Marques, "Viajar em Portugal, nos séculos XV e XVI", Revista da Faculdade de Letras. História, Série II, Vol. 14, Porto, Faculdade de Letras da Universidade do Porto, 1997, p. 99.

${ }^{38}$ Margarida Ribeiro, Estudo..., cit., p. 108.

39 Todavia, sabemos não se tratar da mesma artéria, uma vez que o topónimo atribuído à Rua da Estalagem se deve à existência, neste local, de uma pensão no princípio do século XX.

${ }^{40}$ António José Falcão, "O sagrado e o quotidiano: Aspectos do património religioso do concelho de Coruche", in Cristina Calais (coord.) O Homem e o Trabalho - a magia da mão, Coruche, Município de Coruche/Museu Municipal, p. 93.

${ }^{41}$ Fernando Branco Correia, «art. cit.», p. 81.

${ }^{42}$ Margarida Ribeiro, Estudo..., cit., p. 123. 
Ordem, entre 1532 e 1533, aquando da sua passagem por Coruche, vindo do Escaroupim, deparou-se com uma casa isolada, que identifica como sendo a antiga leprosaria ${ }^{43}$.

Uma outra referência à existência da gafaria, em Coruche, chega-nos pelo já referido testamento de Maria Raimundo de 1339, ao destinar 50 libras para serem distribuídas em obras nas igrejas de Coruche, pelas albergarias e gafarias da mesma vila e vários conventos de Santarém ${ }^{44}$.

No que diz respeito às confrarias de S. Brás e de Nossa Senhora da Conceição seriam possuidoras de vastos bens e rendimentos ${ }^{45}$. A primeira destas teria a seu cargo um hospital, que mais tarde viria a ser administrado pela Misericórdia de Coruche.

A criação de uma Santa Casa da Misericórdia em Coruche, no decurso da segunda metade do século $\mathrm{XVI}^{46}$, deve-se, seguramente, à necessidade de encontrar novas formas de assistência sentidas nesta época. $\mathrm{O}$ mais antigo documento que lhe faz referência directa é um testamento datado de $1555^{47}$.

Desconhecendo-se até ao presente momento a data exacta da sua fundação, sabe-se que a autonomia da instituição apenas se verificou aquando da anexação das confrarias de Nossa Senhora da Purificação, de S. Brás e de Nossa Senhora da Conceição ${ }^{48}$, em alvará, de 1564 , assinado pelo Cardeal D. Henrique, primeiro Arcebispo de Évora. Por um lado, as dificuldades financeiras então vividas pela recém-criada Misericórdia e, por outro, a má gestão experimentada pelas confrarias em questão, concorreram para a incorporação destas na Misericórdia $^{49}$. No alvará aludido, D. Henrique refere-se às confrarias de Nossa Senhora da Purificação e de S. Brás, onde afirma "que a dita confraria era mal regida por seus mordomos e sua renda por elles mal recadada" ${ }^{50}$.

${ }^{43}$ Suzanne Daveau, "La Barque de Passage et les Ponts de Coruche, du XIV au XVI ${ }^{\mathrm{e}}$ Siècle", in Estudos de Homenagem a Mariano Feio, Lisboa, 1986, p. 183.

${ }^{44}$ Maria Ângela Beirante, «art. cit.», p. 252.

45 António José Falcão, «art. cit.», p. 94.

${ }^{46}$ Ver Costa Goodolphim, As Misericordias, Lisboa, Imprensa Nacional, 1897, p. 323. $\mathrm{O}$ autor, sem revelar as suas fontes, aponta o ano de 1550 para a criação da Misericórdia de Coruche.

${ }^{47}$ Arquivo Histórico da Santa Casa da Misericórdia de Coruche (doravante, AHSCMC), Documentação avulsa não catalogada, testamento de Cristóvão Fernandes.

${ }^{48}$ Margarida Ribeiro, Estudo..., cit., p. 167.

${ }^{49}$ Ver Isabel dos Guimarães Sá, Quando o rico de faz pobre: Misericórdias, Caridade e Poder no Império Português, 1500-1800, Lisboa, Comissão Nacional para as Comemorações dos Descobrimentos Portugueses, 1997, p. 38.

${ }^{50}$ AHSCMC, doc. 353. 
No momento seguinte à anexação das confrarias apresenta-se-nos o contrato, datado de 11 de Fevereiro de 1575, com o mestre pedreiro João Lopes para que fosse construída a igreja da Misericórdia ${ }^{51}$. A avaliar pela data da licença concedida pelo Arcebispo de Évora, em 22 de Junho de $1584^{52}$, permitindo a celebração da missa na dita igreja, pressupõe-se que a conclusão da obra tivesse ocorrido próxima desta data.

Caracterizada, em 1758, pelo pároco Leite Pitta, como um "Templo sentuozo" 53 , é uma igreja de uma só nave, sem arco de cruzeiro, apresentando uma fachada de três corpos, ladeada de duas torres sineiras, tendo ao centro o brasão da Misericórdia, do século XVIII ${ }^{54}$. O altar está orientado no sentido Nascente/Poente, com a fachada para a actual Travessa da Misericórdia que, no século XVI, era denominada de Rua da Ostiaria ${ }^{55}$.Em documentação do século XVII é mencionada a existência da Rua de Trás da Misericórdia ${ }^{56}$.

À igreja da Misericórdia estava associado o hospital por si administrado, sendo que aqui funcionou o hospital de Coruche até ao século $\mathrm{XX}^{57}$. A memória do antigo hospital é mantida pela persistência do topónimo Travessa do Hospital.

Igualmente o recolhimento de freires franciscanos deixou a sua marca na toponímia actual, nomeadamente na Rua de S. Francisco, onde se localizava. Neste recolhimento, com igreja própria de invocação de Santa Rosa de Viterbo, residiam, no século XVIII, seis frades ${ }^{58}$. Foi extinto em 1834 . O edifício onde funcionou o recolhimento terá sido demolido, 90 anos depois da extinção do convento, em 1924, para que nesse espaço fosse construída a casa de residência dos magistrados da comarca ${ }^{59}$.

\section{O rio Sorraia e as pontes}

O rio é um elemento determinante na história da região de Coruche e das suas gentes, visto desde sempre como um recurso indispensável. Para além da importância que a navegabilidade lhe conferiu, tendo sido um excelente

${ }^{51}$ AHSCMC, doc. 2.

${ }^{52}$ AHSCMC, doc. 4.

${ }^{53}$ Margarida Ribeiro, Estudo..., cit., p. 298.

${ }^{54}$ Gustavo de Matos Sequeira, Inventário Artístico de Portugal - Distrito de Santarém, vol. III, Academia Nacional de Belas Artes, Lisboa, 1949, p. 32.

${ }_{55}^{55}$ Margarida Ribeiro, Estudo..., cit., p. 108.

${ }^{56}$ Idem, ibidem.

${ }^{57}$ Actualmente, o mesmo edifício acolhe uma clínica médica particular, mantendo o edifício uma continuidade no que diz respeito à sua função.

${ }^{58}$ António José Falcão, «art. cit.», p. 96-97.

${ }^{59}$ Boletim da Junta de Província do Ribatejo, Santarém, 1937-1949, p. 428. 
corredor de entrada e escoamento de produtos, é um provedor de alimentos, não olvidando o facto das sucessivas cheias contribuírem para a fertilização dos campos envolventes.

Se em algumas alturas do ano a corrente era mais diminuta e o rio podia ser passado a vau, segundo nos testemunha o Padre Leite Pitta, no século XVIII ${ }^{60}$, dada a instabilidade do seu caudal em épocas de cheias, a transposição do leito tornava-se, por vezes, difícil, dado que a subida abrupta das águas originava repetidas reparações das pontes, o que acarretaria custos avultados. Assim se explica a decisão de D. Afonso V, em 1450, ao estipular que se mantivesse o estabelecido pelos dois monarcas seus antecessores em relação à aplicação das coimas da justiça na sua reparação $0^{61}$. Também nos Capítulos das Cortes de Évora de 1491, o procurador do concelho, Vasco Nunes, reivindica para o concelho de Coruche o montante anteriormente destinado à construção de um chafariz na Erra. Atende o rei a este pedido, devendo a quantia anteriormente estipulada para o dito chafariz ser usada na reparação das pontes ${ }^{62}$. Reportamo-nos a pontes construídas em madeira, logo mais frágeis no momento de fazer frente à força das águas em tempos de cheias e portanto facilmente destruíveis.

Margarida Ribeiro menciona a alusão feita a uma ponte de pedra, nomeadamente no translado feito em 1443 do testamento de Maria Raimundo (1339), perto da Courela das Marinhas ${ }^{63}$. Nas Memórias Paroquiais, Leite Pitta descreve a existência de uma ponte de pau sobre o Soro, caudal do rio que passava mais próximo da vila, e uma ponte de pedra sobre o Sorraia, com menor caudal que o primeiro e que corria pelos campos $^{64}$. Desconhece-se se estaria a referir-se à mesma ponte aludida no translado do século $\mathrm{XV}$, embora não tenha sido encontrada qualquer referência à dita ponte em outra documentação do mesmo período ${ }^{65}$.

Ainda hoje existe a esquecida Ponte da Coroa, cujas reparações eram feitas recorrendo-se às sisas reais. Ostenta a data de 1828 e permitia a passagem pelo Pego das Armas, uma das zonas mais perigosas do rio.

À semelhança do que acontecia na maioria dos cursos de água, a transposição do rio era simultaneamente feita por intermédio de uma barca de passagem, que, no caso de Coruche, era propriedade da Ordem de Avis, detentora do seu

\footnotetext{
${ }^{60}$ Margarida Ribeiro, Estudo..., cit., Doc. n. ${ }^{\circ}$ 42, p. 300.

${ }^{61}$ Fernando Branco Correia, «art. cit.», p. 84.

${ }^{62}$ Margarida Ribeiro, Estudo..., cit., p. 127.

${ }^{63}$ Idem, ibidem, p. 130.

${ }^{64}$ Idem, ibidem, Doc. n. ${ }^{\circ} 42$, p. 300.

${ }^{65}$ Idem, ibidem, p. 130.
} 
monopólio, possivelmente desde o século XII ${ }^{66}$. A gestão da barca foi depois objecto de desentendimentos entre o comendador da Ordem e os homens do concelho, nomeadamente em 1393, quando o concelho se queixa que o comendador não conservava a barca no porto público, o Porto de Évora, no actual Monte da Barca ${ }^{67}$.

Dada a relação com o rio, existiam vários portos em Coruche, como, por exemplo, o já referido Porto de Évora, o Porto de João Ferreira, que segundo Margarida Ribeiro, seria o principal, para além do Porto de João Felício, o Porto Zambado e o Porto da Palhota (a montante do Monte da Barca), estes últimos com menor movimentação.

Quanto às pontes de madeira, estas persistiram até aos inícios do século XX. Ainda na acta da Sessão de Câmara de 18 de Novembro de 1886, o Presidente da edilidade mostra urgência em que se proceda ao alargamento da Travessa de Valadares "por esta travessa ser muito estreita a ponto dos carros não poderem transitar por ela e mesmo por ser o principal ponto de transito para a ribeira na parte onde existe a ponte sobre o rio Sorraia" 68 .

Em 13 de Abril de 1912 é publicado em Diário do Governo o concurso para a construção de uma ponte sobre o Sorraia e outra sobre o Sorraia Velho (braço do rio mais afastado da vila). Em A Gazeta de Coruche a notícia é de tal maneira exultada, que o caderno de encargos da empreitada foi publicado na íntegra ${ }^{69}$. O director do periódico refere que "ha muitos annos a esta parte que se falla na execução d'este melhoramento, cujas vantagens são por todos conhecidas como obviamente manifestas" $"$.

A certeza porém reside no facto de que esta ponte de madeira só viria a ser substituída definitivamente em 16 de Agosto de 1930, data da inauguração da primeira ponte metálica, com o nome do General Teófilo da Trindade, na altura presidente da Junta Autónoma de Estradas, contando o evento com a presença do Presidente da República, o General Óscar Carmona ${ }^{71}$.

A importância do rio na vida dos que habitaram a vila é algo indiscutível e bem visível nas actividades que o rio potencia. São disso exemplo os pescadores. Alguns do concelho, outros, integrados num movimento migratório sazonal

${ }^{66}$ Fernando Branco Correia, «art. cit.», p. 84.

${ }^{67}$ Margarida Ribeiro, Estudo..., cit., p. 144-145.

${ }^{68}$ Arquivo Municipal de Coruche (de agora em diante AMC), Livro de Actas da Vereação, 1885-1887, fl. 56v.

${ }^{69}$ A Gazeta de Coruche, n. ${ }^{\circ}$ 18, ano 1, de 28 de Abril de 1912, p. 2 e 3.

${ }^{70}$ Idem, ibidem, p. 1.

${ }^{71}$ Esta seria a primeira das 8 pontes a serem construídas, sendo que a última foi terminada em 1938. 
(neste caso nos meses de Inverno), que se registou a partir da segunda metade do século XIX, de famílias inteiras de pescadores oriundos do litoral centro e norte do país ${ }^{72}$. Aos pescadores associam-se as peixeiras e o mercado de peixe, localizado junto ao rio, no Porto de João Ferreira. Mas não podemos esquecer as lavadeiras ${ }^{73}$, actividade exercida exclusivamente por mulheres, que subsistiu até à primeira metade do século XX.

Outrora, era para o caudal do rio que escoavam todos os detritos da vila, esgotos e águas sujas, logo este era um foco de maus cheiros. Na época estival, no leito seco do rio fazia-se criação de animais, como porcos e aves domésticas, um perigo para a saúde pública, assunto cada vez mais abordado nas reuniões da Vereação, à medida que o tempo avança e se entra no século XX.

Ora, pode aventar-se que a zona ribeirinha, por estas características, era então considerada um local menos nobre dentro do aglomerado urbano. A disposição do tecido urbano é denunciadora do que acabámos de dizer. Se atendermos à implantação das principais e mais antigas casas, percebemos que há um claro voltar de costas em relação ao rio. É para a zona ribeirinha que estão virados os logradouros e pátios, áreas de serviço, ligados ao trabalho, e as fachadas direccionadas para o interior do espaço urbano. A vila organiza-se ao longo da principal artéria, a Rua Direita, e da praça central, mas desviando, deliberadamente, o olhar do rio e da zona ribeirinha. Ora, podemos assim dizer que o rio é um elemento duplamente definidor da tessitura urbana: se por um lado é uma barreira natural que confina o espaço da vila a uma das suas margens (visto que a margem esquerda do rio é reservada inteiramente à actividade agrícola), por outro lado, as características próprias do labor do rio condicionam a morfologia das construções e reflectem o modo de vida de uma população.

Pode inferir-se que, com o aparecimento do caminho-de-ferro em Coruche, o ramal Setil-Vendas Novas, inaugurado em 14 de Janeiro de 1904 pelo rei D. Carlos, e paralelamente o progressivo assoreamento do rio, conduz ao decair do transporte de mercadorias por via fluvial. O rio deixa de ter uma das principais funções que desempenhou até ao princípio do século XX: a via de comunicação

${ }^{72}$ Muitas das famílias que migraram para as margens tanto do rio Tejo como do rio Sorraia eram provenientes da Vieira de Leiria, pelo que ficaram apelidados como avieiros. Para mais informações sobre a temática, no que a Coruche concerne, deve consultar-se Luís Batalha, "O Rio, a Pesca", in Vagas Leves - Rostos do Rio, Museu Municipal de Coruche, 2003, p. 31-45.

${ }^{73} \mathrm{Na}$ fonte publicada por Nazareth e Sousa são contabilizadas 9 lavadeiras existentes na vila de Coruche, em 1789. Porém, esta contagem não considerou nestes cálculos os "criados". Cf. Manuel Nazareth e Fernando de Sousa em A demografia portuguesa em finais do Antigo Regime - aspectos sociodemográficos de Coruche, vol. 4, Lisboa, Livraria Sá da Costa Editora, 1983, p. 121. 
por excelência para trocas comerciais. Este abandono das actividades ribeirinhas conduziu à lenta decadência dos portos que existiam junto ao rio. Alguns deles só chegaram até nós uma vez mais através da toponímia local, sendo disso exemplo o já citado Largo do Porto João Ferreira, o Largo do Porto João Felício, mas também a Travessa do Porto Zambado e a Rua do Porto Ferreira.

Curiosamente, na actualidade, a vivência da proximidade do rio é sentida de uma forma diferente. A tendência nos nossos dias é a de privilegiar a vista para o rio e usufruir do espaço como zona de lazer.

\section{Mutações e vivências no/do espaço urbano contemporâneo}

O espaço urbano é um espaço vivo e como tal vai sofrendo mudanças e alterações na sua fisionomia, como se expôs na introdução. As mutações verificadas em cada lugar são marcas da história e da vida quotidiana dos que o habitam, testemunhos das decisões daqueles que detêm o poder e controlam a vida do espaço em cada época. Os factores de ordem natural são, igualmente, responsáveis por estas alterações, muitas delas impossíveis de prever, só permitindo a intervenção humana depois do sucedido. Exemplo disso são os terramotos, motivadores de destruições e ruína de muitos edifícios, pelo que, por vezes, a consequente reconstrução dos mesmos adultera por completo as suas características passadas.

Coruche, vila situada perto da falha do Vale Inferior do Tejo, tem sentido vários abalos sísmicos, ao longo do tempo. Segundo Margarida Ribeiro, os terramotos de 1531, 1903 e 1909 tiveram consequências muito ruinosas em Coruche $^{74}$. Mas, por certo, outros foram fortemente vivenciados na região, como o de 1755. Segundo as Memórias Paroquiais, foi sentido de tal maneira que quase todas as pessoas da vila se refugiaram no santuário de Nossa Senhora do Castelo, mas não trouxe ruína "que possa servir de memória"75. Quanto ao terramoto de 11 de Novembro de 1858, conquanto Joaquim Veríssimo Serrão informe que terá provocado a ruína pelo menos na igreja da Misericórdia, não são adiantados mais pormenores ${ }^{76}$, e nos registos das reuniões da irmandade não foi feita qualquer referência nem ao abalo sísmico nem, tão pouco, a eventuais estragos.

Aos sucessivos tremores de terra é vulgarmente atribuído o desaparecimento da igreja matriz da praça. Margarida Ribeiro adianta que a igreja terá ficado

\footnotetext{
${ }^{74}$ Margarida Ribeiro, Estudo..., cit., p. 174.

${ }^{75}$ Idem, ibidem, p. 299.

${ }^{76}$ João Paulo Narciso, "Terramoto de 11 de Novembro de 1858 e os seus efeitos em Santarém", jornal Correio do Ribatejo, n. ${ }^{\circ}$ 6125, Santarém, 07.11.2008, p. 8.
} 
arruinada em consequência do terramoto sentido em 1531, sendo que, posteriormente, os abalos de 1903 e 1909 a terão destruído completamente ${ }^{77}$. Parece-nos pouco provável que durante um período tão alargado de tempo o edifício da matriz não fosse alvo de obras e reparos, caso fossem de facto necessários. Por sua vez, a tradição oral veicula que a igreja ficou arruinada com o grande terramoto de 1755. Com efeito, o abalo foi também muito sentido na região de Coruche, mas Leite Pitta não é suficientemente contundente a respeito da destruição desta igreja. Importa referir que em 1754, um ano antes do terramoto do $1 .^{\circ}$ de Novembro, foram feitas obras de douramento do retábulo e da tribuna da capela-mor ${ }^{78}$. Ora, se a igreja estivesse já em mau estado de conservação, porquê o investimento no processo de douramento de parte do seu interior?

Certo é que, cerca de meio século depois, através da leitura do termo da reunião de 8 de Janeiro de 1803, presente nos Acórdãos da Mesa da Misericórdia (1802-1818), percebemos que a igreja matriz "se acha[va] inteiramente arruinada, a parte do tecto cahido, estando exposto o Santissimo Sacramento a ficar debacho das Ruínas da mesma Igreja". A referência ao estado da igreja fica a dever-se ao pedido feito pelo Reitor da matriz, à Mesa Administrativa da Misericórdia, para que a Real Colegiada de S. João Baptista se pudesse servir da igreja desta última, visto reunir as condições necessárias, ou seja, "se acha[va] com aceio, decência e sacrario"79. Desta forma, passa a condição de matriz para a igreja da Misericórdia a partir do ano de 1803. Daqui se infere que nesta data a igreja se encontrava num estado calamitoso.

No termo da reunião da Mesa de 12 de Setembro de 1818, os administradores da Santa Casa mostram-se descontentes com o facto de a Real Colegiada, descrita como "sendo a Igreja a demaes grande e sollidos Rendementos da Provencia dAlentejo, exceptuando a Cathedral deste Arcebispado de Évora" ${ }^{80}$, não participar nos reparos que, nos últimos quinze anos, foram necessários fazer no templo que também ocupavam, chegando-se à conclusão que "a Rezidencia da Collegiada na Real Caza da Mizericordia hé munto prejudencial"81. Por aqui se vê que as relações entre a Colegiada e a Misericórdia nem sempre foram totalmente pacíficas, pois, em 1843, o termo da Mesa Administrativa de 13 de

${ }^{77}$ Margarida Ribeiro, Estudo..., cit., p. 174. Uma vez mais a autora não cita as fontes que sustentam esta afirmação.

${ }^{78}$ Processo de edificação da igreja matriz de Coruche, Biblioteca Nacional (Lisboa), ACL-MCO/Cx5, Maço 5.

79 AHSCMC, Livro de Acórdãos, fl. 3v.

${ }^{80}$ AHSCMC, Livro de Acórdãos, fl. 27.

${ }^{81}$ AHSCMC, Livro de Acórdãos, fl. 28v. 
Agosto reflecte novamente desentendimentos entre ambas as partes, uma vez que o Reitor da Colegiada pede para as portas laterais da igreja serem alvo de reparação, visto que se "achavão em estado deplorável" "82, exigindo à proprietária da igreja que as mandasse arranjar. A esta exigência a Misericórdia responde que não poderia ser só da sua responsabilidade o concerto das ditas portas, visto a Colegiada fazer, igualmente, uso da igreja.

Além disso, parte-se do pressuposto de que a relação entre ambas as partes era entendida como provisória. Isto, porque havia a intenção, por parte da Real Colegiada, de ter a sua própria igreja, se não pela via da reconstrução da antiga, dado o seu elevado grau de destruição, ao menos pela construção de um novo edifício (Figura 2). Contudo, o intento encontrou alguns obstáculos, nomeadamente sobre quem deveria recair o encargo do pagamento da obra. O processo chegou à Mesa da Consciência e Ordens em 1824, mas também ele não é explícito quanto ao motivo que esteve na origem da destruição da igreja ${ }^{83}$. A este respeito, acreditamos ser possível acrescentar que aos estragos que, eventualmente, o templo foi sofrendo, se tenha somado a incúria dos responsáveis. De tal modo, que no processo de 1824, o edifício é descrito como tendo chegado "ao último ponto de ruina, de maneira que todos os fieis temem com razão justissima o intrar dentro dela, porque a todo o instante se espera que abatam uns telhados" e mais adiante é lamentado o "mais lastimoso estado de indecencia e de ruina e taõ eminente o abatimento dos seus tectos e telhados que pouco depois deste exame sucedera cahirem por terra", ficando portanto "a Igreja sem uso algum para os Oficios Divinos".

O grau de destruição, associado ao desleixo, é-nos relatado em 1850, em tom inflamado, num artigo do jornal $A$ Nação, afirmando que as sepulturas haviam sido profanadas, uma vez que a igreja "foi arrasada pelos philosophos do camartello, e as pedras dos altares, baptisterio, etc. foram servir para as estrebarias d'um ricasso das visinhanças (...)" ${ }^{\prime 4}$.

Ora, foi, portanto, a igreja da Santa Casa da Misericórdia aquela que funcionou como sede de paróquia da vila até 1958, ano em que ficou concluída a construção da actual igreja de S. João Baptista, no Largo do Terreiro do Brito. Acreditamos que o desaparecimento definitivo, inclusivamente da memória colectiva, da igreja da praça, como era localmente denominada, se tenha

\footnotetext{
${ }^{82}$ AHSCMC, Livro de Acórdãos, fl. 136v.

${ }^{83}$ Processo de edificação da igreja matriz de Coruche, Biblioteca Nacional (Lisboa), ACL-MCO/Cx5, Maço 5.

84 "Os Crimes, ou Delictos", in A Inquisição de 1850 - Os artigos que sob este título publicou o jornal A Nação, Cap. IV, Lisboa, 1850, p. 53.
} 
ficado a dever à falta de convenientes arranjos e reparações. Em 26 de Julho de 1857 foi destruída a última parte que dela restava. A torre sineira foi demolida, sob o patrocínio de um particular, receando a queda eminente e consequente destruição da sua habitação, situada na praça, transladando-se os três sinos aí existentes para o campanário, construído para o efeito, em frente à igreja de S. Pedro ${ }^{85}$. No artigo assinado por um Autentico Coruchense no jornal $O$ Sorraia, é referido, em tom de gracejo, que o "desafinado badalar [destes sinos] muito contribuem para agravar o sofrimento dos infelizes doentes do hospital que lhe fica fronteiro" ${ }^{\$ 6}$, sinal de que a transferência não foi do agrado de todos os moradores.

Como se sabe, o Liberalismo extinguiu várias colegiadas em todo o território nacional, posto que, em 1848, desapareceriam as que tivessem menos de sete beneficiados e com rendimentos inferiores a 80 mil réis por ano. A Colegiada de S. João Baptista de Coruche foi uma das que conseguiu manter-se, juntamente com as de Santa Maria Oliveira de Guimarães, da Cedofeita, no Porto, de Santa Maria da Alcáçova, de Santarém, de Santa Maria, de Barcelos, e de Santo Estêvão, de Valença, embora não pudesse ter mais de 11 beneficiados nem rendimentos superiores a 150 mil réis anuais ${ }^{87}$. Em Diário de Governo de 30 de Setembro de 1850 são publicados os estatutos da Real Colegiada de Coruche, constituída por um Reitor, dez beneficiados, distribuidor, apontador, mestre de cerimónias, regente de cantorias e coro ${ }^{88}$. A extinção da Real Colegiada de São João Baptista de Coruche ocorre aquando da morte do último beneficiado, em 27.11.1901, não deixando de ficar registado, o ocorrido, em acta da vereação ${ }^{89}$.

Em 23 de Abril de 1909, a terra estremeceu num novo abalo, de forte intensidade e com epicentro no Vale do Tejo, sentido também em Coruche, embora não tenha sido das zonas mais afectadas, como foi o conhecido caso de Benavente. Em Coruche, o receio foi grande, pelo que “ficar em casa n'essa noite ninguem quis e por isso os largos que há por esta villa ficaram coalhados de gente em cujas caras se retratava o susto" ${ }^{\circ}$. A cadeia, localizada no edifício

${ }^{85}$ Jornal $O$ Sorraia, n. $^{\circ}$ 42, Ano I, Coruche, 03.08.1930, p. 1.

${ }^{86}$ Idem, ibidem.

${ }^{87}$ Paulo Drumond Braga, "Igreja, Igrejas e Culto", in Nova História de Portugal - Portugal e a instauração do liberalismo, vol. IX, Lisboa, Editorial Presença, 2002, p. 330.

${ }^{88}$ Margarida Ribeiro, Estudo..., cit., p. 116.

${ }^{89}$ AMC, Livro de Actas, sessão de 09.12.1901, fl. 5.

${ }^{90}$ Maria Gabriela Mota Marques, "Quando as águas e a terra se revoltam - Calamidades Naturais no Ribatejo: As cheias e os terramotos (1901-1920)", Revista Portuguesa de História, t. XXXIV, Faculdade de Letras da Universidade de Coimbra, 2000, p. 189-190. 
dos Paços do Concelho, ficou em tão mau estado que os presos tiveram que ser transferidos para Santarém ${ }^{91}$. Na realidade, todo o edifício terá sido afectado, mas foi "a egreja da Misericórdia aquella que mais sofreu" 92 . Na acta da reunião da Mesa Administrativa de 2 de Maio de 1909 ficou bem patente o grau de destruição do edifício do hospital:

"tendo o hospital sofrido com o tremor de terra [...] deixando-o em estado que todas as pessoas que n'elle se abrigam correm o risco de n'elle ficarem subterradas, isto principalmente porque a terra continua a oscilar, [e que se] mande immediatamente construir uma barraca em logar que se julgue conveniente e que para ella se transporte com as comodidades que se possa todos os doentes que se acham no referido hospital e respectivo pessoal." ${ }^{93}$

Ora, uma vez que o edifício do hospital se encontra adossado à igreja da Misericórdia, as probabilidades de esta ter sentido violentamente o sismo, causando-lhe graves danos, são, por certo, muito elevadas. A Santa Casa recebeu, aliás, da parte da Comissão Nacional então criada para prestar apoio às vítimas do terramoto, a quantia de três contos, trezentos e quarenta mil réis para a reparação do edifício ${ }^{94}$.

As grandes catástrofes atraem beneméritos, como por exemplo o grande proprietário coruchense Luiz Sommer que, nesta ocasião, doou 50 mil réis para ajudar quem precisava. Comum era a realização dos chamados bandos precatórios que, no caso de Coruche, conseguiram angariar cento e sessenta e dois mil réis, para o efeito ${ }^{95}$. À semelhança de outras cidades e vilas atingidas, também Coruche, na ocasião, recebeu a visita do rei D. Manuel II, fazendo-se acompanhar pelo Ministro das Obras Públicas e pelos directores gerais do Ministério ${ }^{96}$. O momento foi captado na reportagem fotográfica de Joshua Benoliel e publicado na Ilustração Portuguesa, no artigo intitulado "Através dos escombros do Ribatejo - o terremoto de 23 d'Abril"97.

Também a igreja de Nossa Senhora do Castelo, sobranceira à vila, foi alvo de arranjos causados por este fenómeno natural, como o prova a procissão realizada em Junho de 1909, com o objectivo de a imagem de Nossa Senhora do Castelo

\footnotetext{
${ }^{91}$ Francisco Câncio, Ribatejo Histórico e Monumental, vol. III, s.n., Lisboa, 1939, p. 12.

${ }^{92}$ Idem, ibidem.

${ }^{93}$ ASCMC, Livro de Acórdãos, fl. 35.

${ }^{94}$ ASCMC, Livro de Acórdãos, sessão de 14.02.1910, fl. 44.

${ }^{95}$ Maria Gabriela Mota Marques, «art. cit.», p. 213.

${ }^{96}$ Francisco Câncio, cit., p. 12; Maria Gabriela Mota Marques, «art. cit.»,p. 177.

97 Jornal O Século - Ilustração Portuguesa, n. ${ }^{\circ}$ 167, 10 de Maio de 1909, p. 607, consultado em http://hemerotecadigital.cm-lisboa.pt, em 23.03.2012.
} 
ser novamente restituída ao templo, uma vez que "tinha sahido por motivo dos arranjos que a mesma capella teve de sofrer ocasionados pelo abalo de terra" 98 .

Depois do exposto, importa chamar novamente a atenção para a planta de finais do século XVIII (Figura 1), à guarda do Arquivo Histórico do Ministério das Finanças ${ }^{99}$, onde os polígonos preenchidos a escuro dizem respeito aos templos que, à data, existiriam em Coruche. De salientar que, em 1789, é ainda representada a igreja matriz de S. João Baptista no centro da praça. Igualmente o rio e os seus dois braços são apresentados na planta, sendo que o mais próximo da vila era apelidado de Soro. Podemos constatar que a Rua Direita atravessa nitidamente o casco urbano de uma ponta à outra e dela se ramifica em artérias secundárias do burgo. Não deixamos de notar o facto de o Bairro Alegre já estar devidamente identificado, assim como, no largo em frente à igreja de Santo António, ter sido assinalado aquilo que pensamos ser o cruzeiro referido na acta da Sessão de Câmara, de 06/09/1905, onde é expressa a intenção de proceder à sua demolição ${ }^{100}$. $\mathrm{O}$ autor da planta assinala a zona do rossio, correspondendo ao espaço ocupado pelo actual Parque do Sorraia, que seria nesta altura um arrabalde, à saída da vila, onde, aliás, e por norma, se situavam os espaços apelidados com este nome ${ }^{101}$. Repare-se, contudo, que segundo a planta, poucas foram as alterações de fundo na estrutura da malha urbana da vila, conseguindo-se facilmente identificar a grande maioria das ruas hoje existentes.

Segundo o testemunho de Luís Leite Pitta, pároco de Coruche, em 1758, morariam na vila 1113 pessoas, em 336 fogos, distribuídas por 22 ruas $^{102}$, enquanto que a fonte publicada por Nazareth e Sousa, indica que, em 1789, a população da vila de Coruche já seria de 1296 pessoas que morariam em 711 fogos.

Mas, embora o desaparecimento de qualquer vestígio, pelo menos à superfície, do edifício da igreja da praça só tenha sucedido há cerca de um século e meio, a sua implantação foi apagada por completo da memória colectiva, razão que explica as imprecisões que a oralidade veicula. A torre que, erroneamente,

${ }^{98}$ Maria Gabriela Mota Marques, «art. cit.», p. 196.

${ }^{99}$ Manuel Nazareth e Fernando de Sousa, A demografia portuguesa..., cit., p. 69.

${ }^{100}$ AMC, Livro de Actas, fl. 21.

${ }^{101}$ Sérgio Luís Carvalho, Cidades Medievais..., cit., p. 39.

${ }^{102}$ Margarida Ribeiro, Estudo..., cit., Doc. n. ${ }^{\circ}$ 42, p. 296. Lamentavelmente, nas Memórias Paroquiais não é feita qualquer menção sobre a distribuição da população no aglomerado populacional, mas contabiliza a totalidade de moradores da única freguesia da vila, S. João Baptista, perfazendo 2851 pessoas, estando aqui incluídos os moradores da vila e os restantes dispersos pelo termo, em 77 herdades. 
tem sido identificada como pertencente à igreja, trata-se, na verdade, da torre do relógio situada junto à fonte pública, para o qual existia um encarregado, a quem era pago pela Câmara Municipal, em meados do século XIX, o ordenado de $12 \$ 000^{103}$.

A torre do relógio e o fontanário foram demolidos em finais do século XIX para que, no espaço por eles ocupado, fosse construído o novo edifício do açougue municipal ${ }^{104}$, naquela que seria apelidada de Rua do Talho, actual Largo do Pelourinho. São, igualmente, desta data, finais do século XIX, a construção dos muros e passeios da actual Praça da Liberdade ${ }^{105}$. Simultaneamente à construção do açougue municipal é projectado um novo fontanário para ser implantado em frente do dito edifício.

De salientar, que tanto nos finais do século XIX como ainda nos princípios do século XX, o abastecimento de água potável, não só da vila de Coruche como das demais aldeias do concelho, era uma urgente necessidade. Era problema antigo, como em tantas vilas e cidades do país. $\mathrm{O}$ tema é recorrente nas discussões das sessões camarárias, testemunho da centralidade do assunto no quotidiano das populações. A limpeza e manutenção de canalizações das fontes existentes, a aquisição de águas de nascentes localizadas em propriedades privadas, ou mesmo a expropriação dos mesmos "para o bem comum", a construção de novos fontanários e condutas que minimizem os eventuais desperdícios são uma preocupação constante. A importância de obras como estas "de tão grande urgencia e de primeira necessidade como é o abastecimento d'água potavel para esta villa, por isso que sem ella não pode esta povoação tornar-se salubre" ${ }^{106}$, argumenta o Presidente da edilidade na reunião de Câmara de 15.06.1904. Tratava-se, igualmente, de questões de higiene e saúde públicas que, por esta altura, são alvo de novas e reforçadas atenções.

A malha urbana vai, assim, sofrendo sucessivas alterações e os diferentes espaços vão mudando a sua função, mas, ao longo do tempo, a praça manteve a sua centralidade no espaço urbano envolvente. Ainda no século XX é o centro da vida de Coruche, onde se situam os Paços do Concelho, que no mesmo edifício aglutinaram vários serviços indispensáveis ao cidadão, como sendo a Câmara Municipal, o Tribunal, as Finanças, a Tesouraria da Fazenda Pública, o Registo Predial, a cadeia e a respectiva casa do carcereiro, e a Junta de Freguesia. Foi o centro do quotidiano da urbe, sede do poder político e outrora

\footnotetext{
${ }^{103}$ AMC, Livro de Receita e Despeza, 1850-1878, fl.16.

${ }^{104}$ AMC, Livro de Conta Corrente com o Tesoureiro, 1884-1885, fl. 25-26.

${ }^{105}$ AMC, Livro de Conta Corrente com o Tesoureiro, 1867-1880, fl. 138.

${ }^{106}$ AMC, Livro de Actas, sessão de 15.06.1904, fl. 68v.
} 
do poder religioso, administrativo, judicial, financeiro e económico. Este é, ao mesmo tempo, um espaço de trabalho mas também de manifestações de sociabilidade diversas, de negócios e de diversões, de religiosidade e de punição. Lugar de convívio e de negócio, dada a existência de inúmeros estabelecimentos comerciais, agências bancárias, nas imediações próximas os correios, assim como o mercado, era também na praça que, ao domingo, se procurava trabalho nos campos. Além disso, quando se pretendia publicitar e fazer um negócio a figura do pregoeiro fazia valer a expressão levar à praça, local próprio para o efeito ${ }^{107}$.

\section{Toponímia da vila de Coruche}

A toponímia de um lugar acompanha as circunstâncias históricas locais e nacionais, sendo reescrita ao sabor dos sucessivos acontecimentos.

Durante o período medieval, porém, não era sentida a necessidade da existência de placas toponímicas, como hoje qualquer aglomerado populacional - por mais reduzido que seja - possui. Logo, a nomeação dos vários espaços de uma localidade era feita de forma empírica e transmitida por via oral ${ }^{108}$. Terá sido a partir de meados do século XIX, com a Regeneração, que a toponímia, e a consequente colocação de placas identificadoras, começou a ser o resultado de uma imposição do poder, como forma de transmissão de determinados valores ${ }^{109}$.

No caso de Coruche, são ainda parcos os conhecimentos relativos à toponímia de períodos mais longínquos. Margarida Ribeiro faz uma breve referência a toponímia dos séculos XVI e XVII, cujo conhecimento obteve através de documentação respeitante à Colegiada de S. João Baptista e à Misericórdia de Coruche. Mas, se para algumas delas, podemos identificar a sua localização para outras, continua uma incógnita. Assim, a autora refere a existência das, já anteriormente mencionadas, Rua das Estalagens, Rua Direita, a

${ }^{107}$ Esta expressão é consecutivamente usada nas actas das reuniões da Vereação e nas actas da Mesa Administrativa da Santa Casa da Misericórdia de Coruche, sempre que se quer arrematar um bem ou um serviço.

${ }^{108}$ Veja-se Amélia Aguiar Andrade, "Conhecer e Nomear: a toponímia das Cidades Medievais Portuguesas", in A Cidade. Jornadas Inter e Pluridisciplinares, vol. 1, Lisboa, Universidade Aberta, 1993, p. 121-140.

${ }^{109}$ Ruy Ventura, “Toponímias de Portalegre: da Idade Média ao século XIX (contributos para o seu estudo)", Ibn Marúan, n. ${ }^{\circ}$ 12, Câmara Municipal de Marvão/Edições Colibri, 2003, p. 411-452. 
Calçadinha (que nos dias de hoje mantém o mesmo nome) e a Praça, em $1632^{110}$. Além destas, revela a existência da Ladeira do Castelo, Rua do Espírito Santo (junto ao edifício da Irmandade com o mesmo nome), Rua da Ponte, Rua de Fernão Ramos, Rua do Bom Nome (actual Rua da Música), Rua Nova (ao presente, Rua dos Lusíadas), Rua de Santarém, Rua de Trás da Misericórdia (possivelmente a actual Travessa do Forno), Rua do Terreiro de S. Pedro, em frente à dita igreja, Rua Direita de Santo António, Rua de Palhais (actual Rua de Santarém) e Rua da Ostiaria, esta última em frente à igreja da Misericórdia.

Pouco ou nada se conhece quanto à evolução da toponímia desde esta altura até aos finais do século XIX. Sabe-se, contudo, pela acta da Sessão de Câmara de 29.01.1890 ${ }^{111}$, com o Ultimato como notícia ainda recente, que é deliberado, por unanimidade, passar-se a denominar a praça da vila como Praça de Serpa Pinto. Desconhece-se se, anteriormente, a praça era apelidada de outra forma; certo é que surge em documentação posterior designada como Praça do Comércio.

Com a chegada da República, algumas artérias foram alvo de renomeações, como aconteceu um pouco por todo o país. Assim sucedeu com a Praça do Comércio que, em Sessão de Câmara de 08/10/1910 ${ }^{112}$ passou a designar-se Praça 5 de Outubro, comemorando o momento, muito recente, da implantação do regime republicano em Portugal e a queda da Monarquia. Na mesma sessão, são alteradas as denominações da Rua Direita, que passa a ser identificada como Rua Cândido dos Reis e o Bairro Alegre que recebe o nome de Rua Miguel Bombarda, tratando-se, como é sabido, de personagens ligados ao partido republicano. Igualmente a Rua da Misericórdia recebe, nesta altura, o nome do também republicano Dr. Manuel Brito Camacho. Dois dias depois $(10.10 .1910)^{113}$, novamente, em reunião de Câmara, o Terreiro do Brito e o Largo de S. Pedro passam a designar-se como Praça 31 de Janeiro e Largo 28 de Janeiro, relembrando as duas tentativas frustradas de derrube do regime monárquico ocorridas em 1891 e 1908, respectivamente.

\footnotetext{
${ }^{110}$ Margarida Ribeiro, Estudo..., cit., p. 107-108.

${ }^{111}$ AMC, Livro de Actas, fl. 76v e 77.

${ }^{112}$ AMC, Livro de Actas, fl. 14v.

${ }^{113}$ AMC, Livro de Actas, fl. 16.
} 
Em 8 de Fevereiro de 1911 é alvo de alteração a avenida marginal ${ }^{114}$ que passa a ser designada por Avenida da República ${ }^{115}$, tendo sido, esta e as anteriores placas toponímicas citadas, descerradas pelo então Ministro do Fomento ${ }^{116}$.

O período da história política seguinte foi igualmente profícuo no que diz respeito à alteração toponímica na vila. Assim, em 1932 é tomada a decisão de nomear o Bairro Novo de Bairro Capitão Luiz Alberto de Oliveira ${ }^{117}$ e, em 1941, procurando apagar as marcas republicanas das ruas, é decidido que as mesmas deverão recuperar o seu nome antigo, abrindo uma excepção para a Rua Júlio Maria de Sousa ${ }^{118}$. Pela Sessão de Câmara de 14.04.1953, a novamente chamada Praça do Comércio sofre mais uma mudança, ao ser apelidada de Praça Dr. Oliveira Salazar ${ }^{119}$. Em 1960 é levada a reunião de Câmara a proposta de nomeação da Rua de Olivença, uma constante em muitas vilas e cidades portuguesas, como que relembrando a vila esquecida em domínio espanhol. Durante o decorrer do ano de 1972 surge a actual Avenida Luís de Camões em substituição da Avenida da República, e a Rua Nova dá lugar à Rua dos Lusíadas, possivelmente num esforço de exaltação dos valores patrióticos e nacionalistas.

Com a Revolução de Abril ainda muito presente, o nome da Praça Dr. Oliveira Salazar é prontamente substituída por Praça 1..$^{\circ}$ de Maio (02.05.1974), denominação logo trocada, por reunião de Câmara, de 9 de Maio de 1974, para a actual Praça da Liberdade. Nas páginas do jornal O Sorraia, de 11 de Maio de 1974, encontramos a descrição de uma manifestação realizada no 1. de Maio desse ano, quando a placa toponímica referente à Praça Dr. Oliveira Salazar foi pintada com a actual denominação ${ }^{120}$. Passados alguns meses, surgem os nomes de Jardim 25 de Abril, anterior Jardim Marechal Carmona, Rua da Música, em vez de Rua João Lopes de Carvalho Júnior, antigo

${ }^{114}$ É possível que esta denominação seja fruto da oralidade.

${ }^{115}$ AMC, Livro de Actas, fl.63v.

${ }^{116}$ AMC, Livro de Actas, fl.71v.

${ }^{117}$ Luís Alberto de Oliveira nasceu em Coruche em 1880 e seguiu a carreira militar, que iniciou no Colégio Militar. Foi nomeado, por Sidónio Pais, Governador Civil de Coimbra e, em 1933-34, ocupou a pasta do Ministério da Guerra. Esteve directamente envolvido em diversas obras realizadas em Coruche, como as pontes sobre o rio Sorraia, o saneamento e abastecimento de água, entre outras. Cf. Heraldo Bento, Um olhar sobre Coruche, Câmara Municipal de Coruche, 2003 , p. 111.

${ }^{118}$ AMC, Livro de Actas, fl.38v. Júlio Maria de Sousa, coruchense, era Coronel-farmacêutico, tendo sido o chefe dos Serviços de Farmácia do Corpo Expedicionário Português.

${ }^{119}$ AMC, Livro de Actas, fl. 62.

${ }^{120}$ Jornal O Sorraia, n. ${ }^{\circ} 316,11.05 .1974$, p. 1-10. 
Presidente do Município, antes apelidada de Rua do Bom Nome, e o Jardim João de Deus, em alternativa ao então Jardim Luís de Oliveira ${ }^{121}$.

São vários os exemplos de denominações funcionais presentes na toponímia, como por exemplo, a Rua do Lagar e a Travessa do Forno, denunciando a presença de tais equipamentos nestes espaços, bem como a Rua do Mercado, depois substituída por Rua António Feliciano Branco Teixeira ${ }^{122}$, actual Rua 5 de Outubro. O mesmo se passa com o actual Largo do Porto João Felício, o Largo Porto João Ferreira, a Rua do Porto Zambado, a Rua do Porto João Ferreira, a Travessa das Atafonas, a Travessa do Hospital, a Rua da Música e a Praça do Comércio.

No que diz respeito a topónimos religiosos, encontramos, no presente, a Rua de S. Pedro, que conflui para o largo do mesmo nome, a Rua da Misericórdia, a Rua de Santo António, com um largo com o mesmo nome associado, e a Rua de S. Francisco, último testemunho no local onde existiu o recolhimento que albergava freires franciscanos.

\section{Considerações finais}

Fica o registo do caso específico da vila ribatejana de Coruche, que conserva ainda características muito próprias de uma localidade ribeirinha, com ligações muito fortes com o rio, visíveis na configuração da malha urbana antiga.

Com este texto procurámos perceber, num largo arco cronológico, e numa primeira aproximação ao tema, como o aglomerado urbano se foi desenvolvendo. Com inúmeros recursos naturais, fonte indiscutível de atracção e fixação humana, a vila estendeu-se ao longo da margem norte do rio Sorraia. A falta de estudos, no que a Coruche diz respeito, sobre esta temática é um facto, daí resultando o desconhecimento de muitos aspectos concretos da história desta vila. Assim, foi fundamental debruçarmo-nos sobre as fontes primárias disponíveis. A consulta, por exemplo, das actas da vereação, confrontando-as com informações recolhidas no arquivo da Misericórdia de Coruche e em publicações periódicas locais, com o intuito de encontrar os factos que corroboram, ou não, o que a tradição oral preserva, parece-nos ter grande relevância. A localização inequívoca da implantação no terreno da antiga igreja matriz de S. João Baptista, bem como aventar as possíveis causas para o seu

\footnotetext{
${ }^{121}$ AMC, Livro de Actas, fl. 89. Sobre o topónimo, ver a nota 118.

${ }^{122}$ António Feliciano Branco Teixeira foi um abastado lavrador e exerceu o cargo de Presidente da Câmara de Coruche em dois mandatos não consecutivos: o primeiro no final da I. ${ }^{a}$ República e o segundo durante o Estado Novo.
} 
total desaparecimento, são alguns dos contributos que podem ser atribuídos a este texto. Ficam também aqui registadas algumas pistas para futuros trabalhos a realizar, porque muito há ainda a fazer nesta matéria.

Na verdade, é na história local, muitas vezes e desmerecidamente considerada de somenos importância, que encontramos as respostas que constroem a identidade e memória colectivas.

Recebido em/Text submitted on: 11/04/2012 Aceite em/Approved on: 13/06/2012 